\title{
Current and Future Challenges Facing the European Union's Energy System
}

Working Paper · May 2016

CITATIONS

0

2 authors, including:

\section{Daniel J. Tulloch}

University of Oxford

11 PUBLICATIONS 12 CITATIONS

SEE PROFILE
READS

69 


\title{
Current and Future Challenges Facing the European Union's Energy System
}

\author{
Daniel J. Tulloch ${ }^{1, *}$ and Ben Caldecott ${ }^{1}$
}

\begin{abstract}
The EU energy system is in the middle of a period of profound change. Financing the transition to a low-carbon EU economy is expected to require $\$ 2.2$ trillion by 2035 , requiring substantial private capital. However, investors are hesitant to commit capital due to many challenges facing the energy system. This review provides a high-level discussion regarding the challenges and the potential solutions to address them. We identify four main challenges: 1) structural challenges and reduced capacity adequacy, 2) an incorrect market framework to value flexibility, 3) the inability to finance the energy transition, and 4) the role of transitional fuels. Against these challenges, four potential solutions are: 1) capacity remuneration mechanisms, 2) demand-side response and consumer empowerment, 3) reforms in emissions trading and renewable subsidies, and 4) improved physical interconnections and governance. The EU's ability to address these challenges will directly impact its position as a global leader in green energy investment.
\end{abstract}

Keywords: Fossil fuels, energy system, electricity market design, renewable policy, Target Electricity Model, energy transition

JEL classification: L94, N74, O16, Q4

${ }^{1}$ Smith School of Enterprise and the Environment, University of Oxford, South Parks Road, Oxford, OX1 3QY, United Kingdom.

* Corresponding author: e-mail: daniel.tulloch@smithschool.ox.ac.uk tel: +44 (0)1865 614934 


\section{Introduction}

The European energy system is in the middle of a period of profound change. To create a resilient energy system, the European Commission introduced the 'Energy Union Package'. ${ }^{1}$ The motivation for the Energy Union is a fundamental shift in the way energy is generated and distributed. Traditionally, European energy was based on a centralised, supply-side model, dominated by stateowned fossil fuel utilities and national policies. The vision for the Energy Union included: 1) international cooperation and harmonisation across Member States, where energy could freely flow across borders; 2) a sustainable, low-carbon and climate-friendly EU economy; 3) competition to encourage firms to innovate and develop low-carbon and energy efficiency technology; 4) increased investors' confidence through price signals which reflect long-term needs and policy goals; and 5) empowering EU citizens to take ownership of the energy transition. Unfortunately, many of these desired objectives have not been achieved to date and the system is faced with many challenges it must overcome to ensure secure, sustainable, affordable and competitive energy for its 503 million citizens. $^{2}$

Reducing emissions from the energy sector is fundamental to addressing risks of anthropogenic climate change, requiring deep decarbonisation of the energy system and a fundamental shift in infrastructure. ${ }^{3}$ The electricity industry is a natural place to begin decarbonisation as it can be achieved at lower cost and with less behavioural and structural change relative to other sectors. ${ }^{4}$ However, the difficulties faced by the energy sector raises many questions: are the challenges temporary or structural? Or do they reflect fundamental flaws in market design, regulation or corporate strategy $?^{5}$ If the problems are structural, utilities and investors may be unable or unwilling to finance the investments, threatening energy security. Poor market design can also result in increased costs, decreased reliability, increased market abuse and competition issues. ${ }^{6}$

Investment risk in the energy sector has also increased due to price volatility and political uncertainty from an unstable regulatory framework. ${ }^{7}$ Energy sector investment is increasingly being shaped by government policies and incentives rather than price signals from competitive markets. ${ }^{8}$ Empirical evidence has shown that major liberalisation and decarbonisation restructuring legislation 
are materially affecting financial returns. ${ }^{9}$ Private investors now consider the sector "non-investment grade" ${ }^{, 10}$ and demand higher yields on energy stocks, ${ }^{11}$ making equity an expensive source of capital. Access to this private investment is crucial as the International Energy Agency (IEA) projects up to \$2.2 trillion of total power sector investment is needed in the EU between 2014 and $2035 .{ }^{8}$

In this review article, we provide a high-level discussion regarding key current and future challenges facing the EU energy sector in its transition towards a low-carbon energy system. We survey a variety of sources to represent a range of perspectives, including: academic literature, policy documents, consultations, and practitioner and third-party reports. In doing so, we identify outstanding knowledge gaps that can be important avenues for further research.

Our review of the existing literature suggests there are four main challenges. First, the sector faces structural challenges including a decline in demand growth and reduced capacity adequacy. Second, the current framework does not provide a sound basis for sector investment and is insufficient at valuing flexibility. Third, incumbents and new entrants are unable to establish the market capitalisations required to finance the energy transition. Fourth, the sector faces committed emissions and premature asset stranding. Against these challenges, we identify four potential solutions. First, the ability of capacity remuneration mechanisms (CRM) to address the capacity adequacy issue. Second, the role of demand-side response (DSR) and consumer empowerment as potential solutions to system flexibility challenges. Third, reforming the European Union's Emissions Trading Scheme (EU ETS) and renewable subsidy schemes to facilitate the low-carbon transition. Fourth, improving the physical interconnections within Europe and creating new governance and regulatory frameworks for the energy system. This paper proceeds as follows. Section 2 outlines the challenges, Section 3 outlines the potential solutions and Section 4 concludes. 


\section{Current and Future Challenges Facing the Energy System}

\subsection{Structural Challenges in Capacity, Demand and Expenditures}

\subsubsection{The Shift from OPEX to CAPEX}

The EU energy system has seen major shifts in the way energy is structured. The current electricity market design assumed large operating expenses (OPEX) technologies with significant variable costs (such as coal-, gas- and oil-fired generators) would supply the bulk of energy. Accordingly, the current market paradigm was designed to induce competition between OPEX technologies and massive support for renewable energy source (RES) generation was unanticipated. The OPEX model was relatively simple as the underlying price of the commodity determined the cost of energy and suppliers charged a premium for energy supply. The OPEX model allowed investments to be written off against annual profits over time. The different types of generation also had defined roles in the energy system: Large units (coal) supplied long-term baseload power, while flexible units (gas) supplied peak demand.

Over the last two decades, the power sector has rapidly shifted towards predominantly high fixedcost capital expenditure (CAPEX) technologies (renewables and nuclear) with near-zero marginal cost to operations. The rapid expansion is partly due to EU policy incentives aimed at reducing carbon intensity. These high-CAPEX technologies affect the wholesale market in three ways: 1) reducing the volume of electricity generated by conventional utilities, 2) lowering average prices, and 3) lowering peak prices. ${ }^{5}$ The latter is of concern as high peak prices are required to incentivise investment in peaking capacity. These issues have contributed to return on capital trending below the cost of capital, reducing value in the energy sector. ${ }^{10}$

\subsubsection{Increased Capacity and Decreased Generation}

Plot A of Figure 1 shows that electricity generation grew by 26\% between 1990 and 2013, and has recently plateaued. Plot B shows installed capacity, the maximum potential output available, increased by approximately $70 \%$ over the same period. As electricity cannot be effectively stored, energy supply and demand must be balanced at all times. Insufficient exit of thermal generation from the 
market, as more renewables come online, can lead to overcapacity and disequilibrium in the panEuropean energy system. A high proportion of RES also poses a second issue: net capacity factor. Net capacity factor represents the actual output from a generating unit relative to its potential maximum capacity. Data in Table 1 shows that the capacity factors of generating technologies vary. RES typically have lower capacity factors and therefore require more units to produce an equivalent amount of electricity compared to large, base-load units. Further, the actual maximum output, for wind and solar can be dependent on site location, and diurnal and seasonal weather patterns. ${ }^{12}$ RES generators only operate in favourable weather conditions, adding little to system reliability, and volatile weather impacts wholesale energy prices. ${ }^{6,13-15}$ Therefore, thermal generators must exit at a slower rate than RES to avoid reliability issues. ${ }^{7}$

\section{[INSERT FIGURE 1 HERE]}

[INSERT TABLE 1 HERE]

The varying capacities and generation profiles across Member States impact emission profiles, national wholesale prices and the incentives to trade across borders; particularly if large price differentials exist between the two markets. Figure 2 illustrates the daily load profiles of the UK and France - which have similar population sizes. The UK (Plot A) has lower energy demand than France, services demand with a variety of OPEX technologies, but is a net importer of energy due to low capacity. In contrast, France (Plot B) services much of its demand with nuclear and exports excess generation.

\section{[INSERT FIGURE 2 HERE]}

\subsubsection{Prolonged Decline in Demand Growth}

Ordinarily, energy demand is linked to economic growth as wealth effects and increased business activity results in greater electricity consumption. ${ }^{16-18}$ Recently, energy demand has begun to decouple from economic growth. ${ }^{5,19}$ Between 2007 and 2013, OECD primary energy demand decreased by 5\% despite GDP growth of almost $4 \% .{ }^{20}$ The decline is partly the result of changes in economic structure, changes in energy consumption, and increased energy efficiency. RES has also contributed to declining energy growth as supporting RES indirectly lead to technological energy efficiency gains. ${ }^{21}$ 
Regardless, decreased energy demand impacts the utilisation of existing generating units and the incentives to build capacity. Some Member States, such as the UK, will find it difficult to justify building or replacing capacity when future energy demand is uncertain and there's little guarantee that investments and operations will be remunerated due to low wholesale prices in the energy-only market.

\subsection{The Energy-Only Market}

The energy-only market represents the traditional basis for wholesale electricity trading, where generators are paid for dispatched electricity and market forces determine value. As supply and demand fluctuate, electricity is not worth the same at every point, nor every place where it is produced and consumed. ${ }^{22}$ High prices during periods of excess demand are referred to as scarcity prices and indicate the system requires more existing capacity. ${ }^{7,19}$ These price signals play an important role in incentivising generation investment as they reflect potential remunerations to utilities and investors.

Electricity generators can be ranked on their short-run marginal costs (SRMC), which is the marginal cost of producing an extra increment (MWh) of energy. ${ }^{15}$ In the energy-only market, generators offer into the market and are remunerated the market clearing price. ${ }^{6}$ The supply curve obtained is known as a merit-order curve. All bids below the clearing price are in the merit, while bids above the clearing price are out of merit. The marginal generator (the last dispatched) sets the price for other market participants. ${ }^{15}$ Figure 3 (Plot A) shows the low marginal cost of RES and nuclear energy means these generators can sometimes out-bid all gas- and coal-fired generation regardless of energy demand. ${ }^{14}$ Plots A and B shows more expensive technologies, such as coal and gas, are brought online when demand and clearing prices increase. RES technologies shift the merit order curve and depress wholesale prices by pulling prices towards zero for increasing periods of

time. ${ }^{6,7,10,13-15,23,24}$ Empirical evidence shows the merit order effects for these technologies range from -2 to $-13 € / M W h$ for each additional GW of installed capacity ${ }^{25}$.

\section{[INSERT FIGURE 3 HERE]}

Table 1 (Column B) shows the low-levelized cost of energy for some RES generators makes them competitive against conventional generators. Many RES are also paid a subsidy for electricity 
provided, independent of the electricity price. These subsidies incentivise production in hours where power prices are below avoidable costs. ${ }^{6,10}$ Further RES often produce electricity during peak hours, especially during summer, which were historically the most profitable hours for thermal generators. ${ }^{11}$ There are concerns that, even without subsidies, the low SRMCs of RES generators will result in their full dispatch in normal conditions ${ }^{15}$ reducing upstream margins for conventional generators. ${ }^{5}$

The annual system price for the Nord Pool Spot, the largest EU electricity market, has fallen from $€ 53.06 / \mathrm{MWh}$ in 2010 to $€ 20.98 / \mathrm{MWh}$ in $2015 .^{26,27}$ Accordingly, many utilities are cautious of future prices and have aggressively hedged almost all electricity output forward with the aim of limiting the impact of spot price swings on short-term earnings. ${ }^{28}$ The downward shift in wholesale prices and reduced investment incentives imply fixed-cost recovery will become a key issue, raising deployment costs for future capacity. ${ }^{4,7,29}$ Future markets, with a large proportion of renewables, may depress average prices below long-run average costs of some RES capacity. ${ }^{30}$ One solution would be to intentionally curtail some RES output. ${ }^{6,14}$

\subsubsection{The 'Missing Money' issue}

Temporarily high prices during periods of scarcity might be legitimately required for peaking units and conventional generators to recover fixed-costs. High prices are politically unpalatable, particularly since the ability for prices to reach very high levels may also be used strategically by market players to abuse market power. ${ }^{7,19,31,32}$ For this reason, some day-ahead and intra-day markets (in EUPHEMIA) ${ }^{13}$ have wholesale price caps. Price caps protect consumers by suppressing prices below the market clearing levels during periods of scarcity, but induce 'missing money'. ${ }^{6,31}$

The 'missing money' issue arises when expected net revenues from sales of energy and ancillary services provide inadequate incentives for investment in new generating capacity ${ }^{7,13,31}$ or do not fully account for the opportunity cost of incremental demand or operating reserves during periods of scarcity. ${ }^{33}$ As prices are disconnected from opportunity costs, lower wholesale prices leave incumbents unable to recoup the necessary return on thermal investments and new entrants cannot establish market capitalisation at the level necessary to finance new base-load assets without additional payments beyond the energy market. ${ }^{5,13,34}$ Reduced investment lowers the necessary 
properties to handle system failures if variable RES is not supported by a constant and reliable energy source. ${ }^{35,36}$ Reserve plants are still essential to managing intermittency and preventing power outages by remaining available to generate electricity during brief periods of scarcity. ${ }^{14}$

Large generators have minimum loads, the lowest level a plant can operate at without completely shutting down, of approximately $50-70 \%$ of the unit's capacity and find it difficult and costly to scale back operations. ${ }^{14,15}$ Some inflexible generators are incentivised to place negative bids into the wholesale market to stay on the system during high demand and/or oversupply as turning off would incur greater costs and risks. ${ }^{6,11,15,37}$ This phenomenon of 'negative pricing', where generators pay rather than be paid to deliver energy, indicates the system requires flexibility improvements. ${ }^{15,33}$

Ultimately, the energy-only market is unlikely to remunerate the fixed-costs of some power stations $^{5}$ and does not produce enough expected life-cycle net revenues to incentivise investment in generating capacity. ${ }^{7,31}$ The market should ensure short-term scarcity situations are reflected in wholesale prices, which convert to long-term investment signals. ${ }^{10}$ Neither a pure-market solution nor complete regulation is likely to determine an adequate level of installed capacity; therefore, a hybridmarket which balances regulation and market mechanisms remains the pragmatic solution. ${ }^{7,10}$

\subsection{Capacity of Incumbents to Finance Investment}

\subsubsection{The Financing Gap}

The third major issue is financing the energy transition. There is a substantial gap between the current levels of investment and those required to reach targets in 2020 and beyond. Based on known national policy commitments and plans, the IEA predicts total investment in the EU power sector is US\$2.227tr between 2014 and $2035 ;^{8}$ illustrated in Figure 4. $\$ 655 \mathrm{bn}$ is required to replace and reinforce aging transmission and distribution grids and $\$ 180 \mathrm{bn}$ is needed to integrate renewables. New generation capacity will cost $\$ 1.6$ trn, three-quarters of which is invested in renewables, increasing the proportion of RES in energy generation from $24 \%$ in 2012 to $44 \%$ in 2035 . Other estimates of required investment vary from $€ 40-90 \mathrm{bn}$ per annum. ${ }^{10,19}$ The EU's annual electricity is $3.1 \mathrm{TWh}^{38}$ at around $€ 55.69 / \mathrm{MWh}$ wholesale, ${ }^{39}$ producing an estimated $€ 172.6 \mathrm{bn}$ turnover in 2015; 
thus, the investment required is $23-52 \%$ of annual turnover. The ability of the sector to finance these investments depends on their capital raising ability of existing and new-entrant utilities.

\section{[INSERT FIGURE 4 HERE]}

\subsubsection{Investment Crisis and Regulatory Change}

The EU energy system is in the midst of an investment crisis and a myriad of regulatory changes are materially affect utilities' financial returns. ${ }^{9}$ The 'patchwork' approach to picking technology winners had led to market distortions, inconsistencies across borders, and suboptimal geographical RES deployment. ${ }^{10}$ The high policy uncertainty and unstable market framework does not provide a sound basis to attract investment as shareholders find it increasingly difficult to be confident that future wholesale electricity prices will remunerate unsubsidized generation. ${ }^{7,13}$ The lack of credibility of investment plans based on forecasted revenues has left the sector 'non-investment grade'. ${ }^{10}$ This poses a challenge as the decline in balance sheet capacity seen in incumbent utilities has not yet been offset by new RES companies or vehicles with the same access to capital.

\subsubsection{The Decline in Credit-Worthiness}

Historically, investment in the energy sector was mostly driven by debt finance. The mid-1990s packages $^{40,41}$ of sector liberalisation introduced privatisation and competition into the electricity and gas industries. The removal of national barriers encouraged a wave of synergistic Merger and Acquisition (M\&A) activity to: 1) expand across borders to gain economies of scale, or 2) allow domestic suppliers to defend against predatory foreign competitors. Simultaneously, a downward revision of organic growth, from 2 to $1.6 \%$, provided an incentive for utilities to fund growth using debt, which had a marginal cost of only $2.4 \%$ after tax. ${ }^{42}$ Figure 5 (Plot A) shows a rapid increase in debt issuance over this period, with vertically integrated utilities being the most active during the M\&A period. ${ }^{43}$

\section{[INSERT FIGURE 5 HERE]}

As the 2008 GFC unfolded, the growth expected by energy utilities did not materialise. Following the GFC, energy demand decreased by $2.5 \%$ in the first quarter of 2008 and a further $4.9 \%$ in the first 
quarter of $2009 .{ }^{44}$ Utilities were left in a highly leveraged position and unable to borrow more ${ }^{45}$ Plot B of Figure 5 shows much of the outstanding debt is also lower-medium or non-investment grade.

Unable to borrow more, utilities turned to off-balance sheet financing ${ }^{46}$ to minimizing total liabilities and keep leverage ratios within acceptable ranges. Off-balance sheet financing became common in the renewables sector, where the output from RES was contracted to a single party under power purchase agreements (PPA). ${ }^{47}$ These financing 'loopholes' existed due to the difficulty in determining whether the PPA contains a lease. If the purchaser takes all the output from a generator, are they paying for the right of use or the asset's output? Further, does the criterion 'fixed per unit of output' mean: 1) prices are not allowed to vary over the contract's term, or 2) the purchaser and seller can predetermined at inception what the exact price will be, for every unit of output sold at each point in time, during the term of the arrangement $?^{47}$ The two interpretations required different accounting policies, but accounting practices have begun to address these issues and close the loopholes.

\subsection{Fossil Fuels, Committed Emissions and Asset Stranding}

\subsubsection{The Role of Fossil Fuels}

With the change in perception towards nuclear after the Fukushima incident, ${ }^{48}$ some thermal generation may be required to support RES in the short- to medium-terms to ensure security of supply. ${ }^{49}$ In absence of significant contributions from nuclear energy or carbon capture \& storage (CCS), combined cycle gas turbines (CCGT) power plants provide a relatively clean, reliable and flexible thermal baseload technology. ${ }^{34,50}$ The fuel efficiency of CCGT technology increased to around 57\% in 2014 compared to $49 \%$ at 1990 levels. ${ }^{51}$ Further, natural gas has a potential role to help meet short-to medium-term emission targets for power generation, heating, and transport in the future..$^{52}$

Despite environmental policies mandating that high polluting technologies improve emission performance or close, carbon-intensive plants which meet the new standards have retained competitiveness against CCGT due to the low cost of carbon and an unsubstantial carbon price. ${ }^{34}$ As of 2013 , coal provided approximately $41 \%$ of the world's electricity needs and around $32 \%$ primary 
energy consumption globally. ${ }^{53,54}$ This trend is likely to reverse as tighter emission standards and carbon prices increase. ${ }^{5}$

\subsubsection{Committed Emissions}

Barring widespread early decommissioning, or retrofitting existing plants with CCS, inertia dictates that the existing power infrastructure is 'committed' to producing substantial $\mathrm{CO}_{2}$ emissions over the next decades as fossil-fuel fired capacity is expected to operate for 40 years. ${ }^{55,56}$ Assuming the most stringent global carbon budget, we have already committed to $89 \%$ of the remaining 2014-2100 electricity generation budget for a $50 \%$ chance of remaining below a $2^{\circ} \mathrm{C}$ increase in global temperatures. ${ }^{56}$ To remain within the carbon budget, all new fossil generating investments must be net-zero by at least $2017,{ }^{56}$ or must be retrofit with Negative Emission Technologies. ${ }^{57}$

A failure to achieve the global carbon budget implies one of two outcomes: A) we accept greater probabilities that global temperatures could exceed $2^{\circ} \mathrm{C}$, or B) we decommission an increasing proportion of generating asset early. Any decision now regarding fossil-fuel generators is subject to lengthy lead times, and significant quantities of energy may not be produced before the early-2020s. Investors will be reluctant to invest in thermal power generation if there is some likelihood that their investments will become prematurely stranded.

\subsubsection{Asset Stranding}

Asset stranding is a material risk that investors must now incorporate into their decision making. When generation assets become uneconomic to operate, plants may be temporarily shut down (mothballed), or permanently retired ahead of planned decommissioning dates. ${ }^{34}$ Through mothballing or decommissioning, and assuming capital costs have not been significantly depreciated, owners may be left with sunk costs which are rendered unrecoverable and are generally considered stranded assets. The 2014 impairment charges in Europe's top-16 power and utility companies amounts to $€ 22.9 \mathrm{bn}$ and are mostly caused by persistently low wholesale prices. ${ }^{58,59}$ However, this must be balanced against the historical allocation of free carbon allowances until 2013, where firm's total profits almost doubled. ${ }^{60,61}$ Total windfall profits are estimated to be between $€ 23$ and $€ 63$ billion between 2008 and 2012). ${ }^{62}$ 


\section{Potential Solutions and pathways towards a new energy framework}

\subsection{Capacity Remuneration Mechanisms (CRM)}

Member States have introduced, or plan to introduce, a number of CRMs to ensure generation system adequacy and solve the missing money issue (Section 2.2.1). ${ }^{4,729,32}$ CRMs can take many forms, but the underlying principal involves making separate payments for available capacity, rather than paying for electricity delivered. ${ }^{22}$ Figure 6 illustrates the taxonomy of CRMs in the EU.

\section{[INSERT FIGURE 6 HERE]}

The experiences of implementing various CRMs across the EU have been mixed. The UK has experimented with capacity auctions to ensure sufficient resources to supply energy when needed. ${ }^{7}$ The auctions take place years in advance of expected delivery, allowing generators to build the capacity required. Typically, old generating plants compete for annual contracts, while new plants can commit for longer contracts and are expected to provide long-term system reliability. ${ }^{7}$ The 2014 and 2015 auctions produced electricity prices $60 \%$ below expectations, at $£ 19.40$ and $£ 18.00 \mathrm{~kW} / \mathrm{year}$, respectively ${ }^{63,64}$ The UK's second capacity auction for 2019/20 saw fossil fuel generators win $71.5 \%$ of the $46.35 \mathrm{GW}$ available. ${ }^{64}$ The UK capacity auction has been criticised for ignoring the role of interconnectors and for excessively valuing the cost of System Operator actions to mitigate loss of load events. In response, there are already calls to change auction rules. ${ }^{65}$ Further, Fiddler's Ferry, a coal-fired winner of the 2015 auction, decided to pay the Government $£ 33 \mathrm{~m}$ in lieu of the capacity agreement, raising issues regarding how robust these capacity contracts are. ${ }^{66}$

Other Member States have also faced obstacles across the CRM designs. Direct capacity payments, implemented in Spain, led to perverse incentives for investment and created a bias towards overcapacity. ${ }^{13,34}$ While Germany's Strategic Reserve has been criticised for being inefficient and distorting market prices. ${ }^{34}$ Further, Germany faces politically induced challenges regarding nuclear energy and struggles with market integration of RES, which are supported by a range of out-of-market payments. ${ }^{7}$ More generally, CRMs are also argued to contradict the objective of phasing out environmentally harmful subsidies. ${ }^{22}$ 
There are also criticisms around providing payments to existing generators. Why provide payments to plants which would otherwise: A) become stranded assets, or B) remain without such payments? The simplest answer is an ideal energy-only market would also pay existing generators. ${ }^{32}$ Furthermore, Member States have differing approaches to determining generation adequacy and are unlikely to agree on the same capacity market design. Overall, both the energy-only and capacity markets rely on regulator and government to determine appropriate level of reliability, and both desires are argued to utilize high spot prices to incentivise capacity investment. ${ }^{7,32}$

\subsection{Demand-side Response, Consumer Empowerment and Smart Grids}

\subsubsection{Demand-side Response}

Incentivising end-consumers to adapt consumption during peak times, known as Demand-side Response (DSR), is a potential method to address system flexibility and adequacy challenges. The existing issue lies in flat-tariffs, which limit the development of effective competition by sheltering consumers from variations in wholesale prices. ${ }^{1}$ Most customers are unaware of electricity’s real-time prices, have no reason to respond to them, or cannot respond quickly, leading to highly-priced, inelastic demand. ${ }^{32}$ Enabling technologies such as smart-grids, smart-metering, smart-homes, selfgeneration, and storage equipment are empowering EU citizens to take ownership of the energy transition, delivers greater flexibility, and potentially reduces consumers' bills. ${ }^{1}$

DSR will increase demand elasticity to the point where energy prices never exceed the value of energy to the average customer. ${ }^{32}$ DSR provides an active role for consumers in the electricity market. First, consumers can voluntarily change their electricity consumption in response to market prices. Second, consumers can bid on power exchanges, changing their demand at given points in time. Third, consumers can change their consumption in response to periods of system stress or peaks, shifting to periods of low-demand. Fourth, generators can gather data on the consumer's willingness to pay during periods of scarcity, facilitating more stable generation practices. ${ }^{19,22}$ 


\subsubsection{Consumer Empowerment}

From a consumer's perspective, the retail cost of electricity has risen in recent years. Retail prices have generally increased to reflect rising taxes and the cost of supporting public policies, such as those relating to renewable power. ${ }^{5,19}$ Between 2009 and 2013, taxes and levies have, on average, increased retail prices by more than $25 \%$ per annum. ${ }^{19}$ To efficiently convey market signals to endconsumers, DSR will require linking wholesale and retail markets, ensuring retail prices reflect variations in wholesale prices. To facilitate the penetration of DSR, wholesale market price caps could be relaxed to provide a greater incentive to for consumers to adapt consumption. ${ }^{36}$ When faced with large economic savings on fuel-bills, end-consumers will be incentivised to conserve energy.

There are, however, major obstacles to DSR uptake. First, it is difficult and expensive to store electricity on consumer's premises. ${ }^{5}$ Storage systems only deliver energy part of the time and have high capital costs per KWh. ${ }^{67}$ Further, storage is only practical if input prices during charging are low and output prices are high. ${ }^{67}$ Second, some consumers' energy demands are inflexible, which results in overpayments. ${ }^{32}$ Extreme prices can negatively impact these consumers who do not have the means to insure against price fluctuations. Ultimately, politicians could, once again, be pressured to curtail these higher prices, striking a balance between the consumers' bills and the generators' remunerations. Third, there are concerns that DSR will not fully eliminate the missing money and

market power issues. ${ }^{32}$ Fourth, although distributed generation allows tailored electricity services and can be more effective and efficient than the existing centralized grid, ${ }^{68}$ balancing supply and demand at all times can be more difficult with many decentralised agents.

\subsubsection{Short-term Markets}

The development of intermittent renewables reinforces the need to reward operational flexibility and dependability on a short time frame. ${ }^{10}$ To correctly value operational flexibility and achieve least-cost RES integration, the EU's short-term markets must be redesigned to address large-scale cross-border flows and high volumes of variable renewable production. Short-term markets should run from the day-ahead of delivery right up to the moment of consumption, providing full access to flexible technologies. As short-term markets approach real-time pricing, energy utilities can better estimate 
actual feed-in and real consumption. ${ }^{69}$ However, trading much closer to delivery does reduce the time allow for response to system imbalances. ${ }^{36}$

\subsection{Public Support, Transitions and Trade-offs in Low-carbon Technology}

\subsubsection{Cost of Emissions}

A major pillar of the EU's emission policy objective is strengthening the EU's carbon market, which covers $50 \%$ of energy emissions and represents a market value of $€ 20$ billion. ${ }^{70}$ In the long-term, a high carbon price can adjust the relative costs of electricity for conventional and low-emission technology, incentivising investment in the latter. ${ }^{5,19}$ However, the existing EU ETS has failed to deliver an adequate, durable and credible carbon price. ${ }^{13}$ Various factors have contributed to the low carbon price, including: 1) parallel mechanisms, e.g. renewable and energy efficiency policies, which undermine the effectiveness of the EU ETS; 2) over-allocation of permits, creating excess supply; and 3) decreased growth following the GFC, where the system was not designed to deal with an economic recession. ${ }^{5}$ As a result, carbon prices are currently below $€ 10 / \mathrm{tCO}_{2} .{ }^{5,10}$

The EU ETS is currently going through a period of significant reforms with the objective of raising carbon prices. The EU has withheld 900 million carbon credits from auction to rebalance supply and demand. ${ }^{71}$ Further, the Market Stability Reserve (MSR) aims to improve the ETS's resilience to major shocks and reduce the number of carbon credits auctioned per annum at an accelerated rate. The EU ETS reforms are expected to increase carbon prices to $€ 30 / \mathrm{t} C \mathrm{O}_{2}$ in 2020 and $€ 70 / \mathrm{t} C \mathrm{O}_{2}$ in $2030 .^{10}$

The 'required' carbon price for low-carbon electricity is difficult to estimate, as it is sensitive to discount dates, fossil fuel prices and future technology capital costs. ${ }^{72}$ There's concern that high carbon prices may reduce the international competitiveness of various Member States through direct and indirect costs of emissions. The lack of a global carbon price may also lead to 'carbon leakage'. Further, since carbon credits represent the same emissions asset, restrictions must be in place to prevent the import of cheap international units for compliance with domestic emission systems. ${ }^{73-75}$ 


\subsubsection{Support Schemes for Renewables}

The expansion of renewables is increasingly policy driven ${ }^{5}$ and support for renewables, in the early stages of development, can been justified to promote low-carbon technologies and make significant advances towards overall emission reduction targets. Table 1 (Column C) shows varying subsidies across technologies; solar, wind and coal receive the greatest support. Support for renewables can come in many forms, but cause distortions in the energy markets by limiting RESs' risk exposure and therefore risk exposure for their investors. Without support, relatively immature RES technologies would be unable to compete in the energy market. However, public interventions must be carefully designed to ensure transitioning from RES subsidy to RES market integration limits market distortions, improves the functioning of the internal market and helps contain EU electricity costs.

The European Commission has identified four key issues regarding RES support schemes. ${ }^{76}$ First, current support schemes are not cost effective and RES are buffered from wholesale price signals, providing no incentive to adapt projects to changes in supply and demand. Second, Member States are fragmented in technologies, demand and support. Subsidies across Member States vary in absolute terms and per MWh, raising concerns of potential "subsidy shopping" which affects upgrading and replacing existing generation capacity. ${ }^{76,77}$ For example, recent UK RES subsidy cuts collapsed a number of small RES companies, ${ }^{78}$ while large companies such as RWE Innogy transferred 1GW (£250m) of allocated UK RES investment capital to projects in the Netherlands and Germany. Early estimates suggest the UK will marginally miss its 2020 RES targets by 3.5 percentage points. ${ }^{79}$ With the UK representing one of the largest energy markets in Europe, this would be a major blow to the EU's climate change efforts. Third, as intimated, low wholesale prices and policy uncertainty reduce incentives to invest in generation capacity. This provokes concerns, particularly in the UK, where the margin of spare capacity over demand is as low as 1.2 to $5 \%$; the lowest in the past decade.$^{80}$ Figure 2 showed that the UK relies on interconnectors to meet energy demand. Fourth, some RES have reached maturity with decreasing associated costs. The revised EU guidelines have begun to acknowledge that aid should respond accordingly to falling production costs. ${ }^{81}$ From 2016, the EU plans to abolish the guaranteed purchase of renewables at fixed prices, but allow State aid as a premium above the market price. $^{76,81}$ 


\subsection{National regulations, Locational signals and network coordination}

The Energy Union Package highlights that the target internal energy market is still incomplete and many 'energy islands' are not connected to their neighbours. ${ }^{1}$ A fully functioning European market should allow energy to move freely to where it is most needed, wanted and valued, reducing costs and increases energy efficiency. Increased interconnections diversifies energy sources, suppliers and routes, which are crucial to ensuring secure, low-cost, efficient and resilient energy supply for all Member States involved. ${ }^{1,732}$ An interconnected grid also reduces generation capacity needed to meet demand by increasing utilisation rates for existing capacity. ${ }^{82}$ It may also be cheaper to integrate large-scale RES into a large, integrated power system as variable generation can be balanced over a wider geographic area and across a greater number of actors. ${ }^{15}$

\subsubsection{Physical: Interconnections and transnational participation}

Regarding physical interconnections, the EU aims to achieve interconnection of at least $10 \%$ of installed electricity production for all Member States. ${ }^{83}$ There are four proposed projects to transport electricity from locations of production to centres of consumption and storage. First, the Northern Seas offshore grid will provide an expected $40 \mathrm{GW}$ of offshore wind capacity by $2020{ }^{84}$ Second, the North-South electricity interconnections in Western Europe will allow RES generated in the Northern Member States to flow south towards the Mediterranean. Third, the North-South Electricity interconnection in Central- and South-Eastern Europe completes the internal market. Fourth, the Baltic Energy Market interconnection plan focuses on ending the relative isolation of the Baltic States and fostering market integration.

Integrating the internal market is expected to result in net economic benefits of $€ 12.5-€ 40 \mathrm{bn}$ per annum by $2030 .^{85}$ However, appropriate allocation of costs between the Member States is a major concern of cross-border infrastructure projects as the costs and benefits vary across countries. Figure 7 shows the ENTSO-E ${ }^{86} 2014$ estimates of total investment costs per country for projects of panEuropean significance, until 2030. Noticeably, the top five Member States are responsible for $71.7 \%$ of total investment.

[INSERT FIGURE 7 HERE] 
Price differentials between two areas results in congestion revenues, ${ }^{82}$ which remunerate interconnectors. As more interconnectors are built, the convergence of international wholesale prices reduces arbitrage profits from price differentials and the incentives for additional interconnectors. ${ }^{13} \mathrm{~A}$ single price would imply overcapacity in transmission and ignores differences in infrastructure, investment and generation among Member States. Thus, a "copper plate" target of 'zero congestion' is inefficient, and efforts should be focused on finding an optimal interconnection point which balances congestion costs against transmission costs. A joint understanding of the benefits of that project for each state, will solve many of the issues encountered today. ${ }^{84}$

\subsubsection{Governance: and the role of DSOs and TSOs}

Increased interconnection will also require greater cooperation among Member States, adherence to competition rules and the independence of regulators. ${ }^{1}$ Transitioning towards integrated grid operations, networks and trading rules will require 1) a change in governance and the role of Distribution- and Transmission-System Operators (DSOs and TSOs), and 2) integration from the macro (European) to micro (local)-level.

At the macro-level, TSOs will need greater cross-border integration. Regional operational centres must be created to manage cross-border energy flows. ${ }^{1}$ TSOs may also need to rely on the price formation on spot and wholesale markets to manage the system and identify where new European interconnections are needed. Congestion revenues can be put to effective use in building Europe's electricity system and reinforcing interconnections. ${ }^{22}$ To facilitate cross-border exchanges more effectively and efficiently, balancing markets will have to cover larger areas with a common approach to managing network congestion, reducing the need for back-up generation and enabling the European energy system to use utilities RES to their fullest extent. ${ }^{22}$

At the micro-level, optimal distribution grid management is instrumental for integrating decentralised, locally-produced renewables. Ideally, electricity prices and/or transmission changes will convey locational signals to guide the location of new generating capacity, build new transmission lines or implement DSR programs. ${ }^{10}$ DSOs will need to take a more active role in system optimisation, have an increased role in optimising between CAPEX and OPEX, provide non- 
discriminatory access to grids, provide system users with information they need to access the grid, and use local flexibility to prioritise access to RES generators or combined heat and power units. ${ }^{10}$ DSOs and TSOs will also require greater cooperation on issues around network planning and operations to establish a well-functioning short-term market.

An increasing link between retail and wholesale markets must also be reflected in the regulatory framework. Intergovernmental organisations, such as ACER, will play a crucial role in coupling electricity markets. ACER will have to shift from a system of recommendations and opinions to enhanced roles with greater independence, power, and regulatory oversight. This will also require greater choice of energy suppliers for EU citizens and perhaps greater protection rules.

\section{Recommendations and Conclusions}

This review paper has provided an overview of current and future challenges facing the EU power generation system based on concerns that the current energy-only market and regulatory framework does not provide the correct signal to incentivise adequate generation capacity. With respect to the current market framework, there are four main challenges, including: 1) structural challenges, 2) the current market paradigm, 3) the capacity to finance the transition, and 4) the need for transitional technology.

The future of the sector will be increasingly shaped by government policy measures and incentives which materially affect returns in the sector. ${ }^{5,8}$ The decreased market capitalisation, increased debt and stranding of generation assets hinders the capacity of incumbents to finance the energy transition. Further, the current energy-only framework was not designed for large-scale deployment of renewables - which have depressed wholesale prices. The market is unable to provide adequate long-term investment signals and private investors now consider the energy system "noninvestment grade". Markets will have a role to play, but it is essential that they work efficiently and interventions which materially affect returns are minimised..$^{5,9}$

The major challenge of redesigning the energy system is how to balance the need for new builds in the near future against the reducing requirement to 2030 and beyond. It is becoming increasingly evident that the transition from conventional to low-emission technology may require some thermal 
technology, but their use should decrease steadily over time. These new-build thermal plants are increasingly like to be decommissioned early, with shorter expected life, which will raise deployment costs. Moreover, the 'correct' amount of conventional generation is still unclear, as technological advances, such as CCS will substantially impact the amount of carbon that can be emitted.

The 'big bang' shift to low-carbon technologies in the immediate future risks becoming a pyrrhic victory in a system and infrastructure that is not technologically capable of handling a high-RES future. The current RES-levels are already impacting firms through reduced remunerations, governments through subsidy costs, and consumers through taxes and levies. While these impacts are expected to decrease with time and technological learning, it leaves RES in position where they are not sufficiently mature to compete in the market against conventional technology without support. Future RES capacity must be coupled with an exit of conventional technologies, combined with significant infrastructure upgrades and enhancements to make the system completely renewableready. Otherwise widespread discontent and a shift in public opinion for reduced system reliability could pressure politicians to return to 'trialled and tested' polluting generators.

Against these challenges, there are four potential solutions. First, the EU is experimenting with a range of capacity remuneration mechanisms, aimed at addressing the capacity adequacy issue. Second, the demand-side response and consumer empowerment are potential solutions to system flexibility issues. Third, reforms in the EU ETS aim to provide a robust and durable carbon price in the EU, coupled with reforms in the parallel support schemes for RES to establish a clear pathway to operational independence. Fourth, improved physical interconnections a new governance and regulatory framework for the energy system can improve network coordination and optimise network operations, production and load. The good news is that many of the issues outlined above have already been recognised and are on the current agenda for practitioners, academics and policy-makers alike. Both at national- and EU-level, real consideration is being given regarding the best way to intervene and address the issues. 


\section{References}

1. European Commission. A Framework Strategy for a Resilient Energy Union with a ForwardLooking Climate Change Policy. COM(2015) , 1-21 (2015).

2. European Union. EUROPA - Living in the EU. (2015). at <http://europa.eu/about-eu/factsfigures/living/index_en.htm>

3. Nature Energy. A world in transition. Nat. Energy 1, 1 (2016).

4. Newbery, D. M. Towards a green energy economy? The EU Energy Union's transition to a low-carbon zero subsidy electricity system - Lessons from the UK's Electricity Market Reform. Appl. Energy (2016). doi:10.1016/j.apenergy.2016.01.046

5. Robinson, D. The Scissors Effect - How structural trends and government intervention are damaging the major European electricity companies and affecting consumers. Oxford Inst. Energy Stud. Pap. EL, 1-37 (2015).

6. Ahlstrom, M. et al. The Evolution of the Market: Designing a Market for High Levels of Variable Generation. Power and Energy Magazine, IEEE 13, 60-66 (2015).

7. Cramton, P. \& Ockenfels, A. Economics and Design of Capacity Markets for the Power Sector. Zeitschrift für Energiewirtschaft 36, 113-134 (2012).

8. IEA. World energy investment outlook. (IEA, 2014).

9. Tulloch, D. J., Diaz-Rainey, I. \& Premachandra, I. M. The Impact of Liberalization and Environmental Policy on the Financial Returns of European Energy Utilities. Energy J. 38, 77-106 (2017).

10. FTI-CL Energy. Towards the target model 2.0: Policy recommendations for a sustainable EU power market design. (FTI-CL Energy, 2015).

11. The Economist. How to lose half a trillion euros. The Economist 27-29 (2013).

12. Keane, A. et al. Capacity Value of Wind Power. IEEE Transactions on Power Systems 26, 564-572 (2011).

13. Newbery, D. Missing money and missing markets: Reliability, capacity auctions and interconnectors. Energy Policy (2015). doi:10.1016/j.enpol.2015.10.028

14. Green, R. \& Vasilakos, N. Market behaviour with large amounts of intermittent generation. Energy Policy 38, 3211-3220 (2010).

15. Riesz, J. \& Milligan, M. Designing electricity markets for a high penetration of variable renewables. Wiley Interdiscip. Rev. Energy Environ. 4, 279-289 (2015).

16. Shiu, A. \& Lam, P.-L. Electricity consumption and economic growth in China. Energy Policy 32, 47-54 (2004).

17. Narayan, P. K. \& Prasad, A. Electricity consumption-real GDP causality nexus: Evidence from a bootstrapped causality test for 30 OECD countries. Energy Policy 36, 910-918 (2008). 
18. Narayan, P. K. \& Smyth, R. Multivariate granger causality between electricity consumption, exports and GDP: Evidence from a panel of Middle Eastern countries. Energy Policy 37, 229 236 (2009).

19. European Commission. Energy economic developments: Investment perspectives in electricity markets. 8014, (Publications office of the European Union, 2015).

20. Statoil. Energy perspectives 2015: Long-term macro and market outlook. (2015).

21. European Commission. EU energy, transport and GHG emissions trends to 2050: Reference scenario 2013. Publications Office of the European Union (2013). doi:10.2833/17897

22. European Commission. Launching the public consultation process on a new energy market design. COM(2015), (2015).

23. Green, R. J. \& Newbery, D. M. Competition in the British electricity spot market. J. Polit. Econ. 929-953 (1992).

24. Newbery, D. M. Competition, contracts, and entry in the electricity spot market. RAND J. Econ. 726-749 (1998).

25. Cludius, J., Hermann, H., Matthes, F. C. \& Graichen, V. The merit order effect of wind and photovoltaic electricity generation in Germany 2008-2016: Estimation and distributional implications. Energy Econ. 44, 302-313 (2014).

26. Nord Pool Spot. About Us. 2015, (2015).

27. Nord Pool Spot. Market Data | Nord Pool. (2016). at <http://www.nordpoolspot.com/Marketdata1/Elspot/Area-Prices/SYS1/Yearly/?view=table >

28. Thomson Reuters. RWE says has sold ahead 90 percent of 2016 power output. Thomson Reuters, (2015). at <http://af.reuters.com/article/commoditiesNews/idAFL8N1343Q420151112>

29. Joskow, P. L. Capacity payments in imperfect electricity markets: Need and design. Util. Policy 16, 159-170 (2008).

30. Edenhofer, O. et al. On the economics of renewable energy sources. Energy Econ. 40, Supple, S12-S23 (2013).

31. Joskow, P. Symposium on 'Capacity Markets'. Econ. Energy Environ. Policy 2, (2013).

32. Cramton, P., Ockenfels, A. \& Stoft, S. Capacity market fundamentals. Econ. Energy Environ. Policy 2, 27-46 (2013).

33. Hogan, W. W. On an 'energy only' electricity market design for resource adequacy. Work. Pap. (2005).

34. Caldecott, B. \& McDaniels, J. Stranded generation assets : Implications for European capacity mechanisms, energy markets and climate policy. Stranded Assets Program. SSEE, Univ.

Oxford 1-62 (2014). 
35. Arvizu, D. et al. in IPCC Special Report on Renewable Energy Sources and Climate Change Mitigation (eds. Edenhofer, O. et al.) (Cambridge University Press, 2011).

36. Energinet. Market Model 2.0: Final report. (Energinet, 2015).

37. DECC. Electricity Market Reform: Consultation Document. (2010). at <https://www.gov.uk/government/consultations/electricity-market-reform>

38. Eurostat. Electricity production, consumption and market overview. (2015).

39. Nord Pool Spot. Historical Market data | Nord Pool Spot. (2016). at $<$ http://www.nordpoolspot.com/historical-market-data/>

40. European Parliament and Council. Directive 96/92/EC of the European Parliament and of the Council of 19 December 1996 concerning common rules for the internal market in electricity. Off. J. Eur. Union 027, 20-29 (1997).

41. European Parliament and Council. Directive 98/30/EC of the European Parliament and of the Council of 22 June 1998 concerning common rules for the internal market in natural gas. Off. J. Eur. Communities 204, 1-12 (1998).

42. The Economist. Europe's coming merger boom. The Economist (2005).

43. Codognet, M. K., Glachant, J. M., Lévêque, F. \& Plagnet, M. A. Mergers and acquisitions in the European electricity sector. Cern. Paris 1-135 (2002).

44. IEA. The impact of the financial and economic crisis on global energy investment. (2009). at <https://www.iea.org/publications/freepublications/publication/impact.pdf>

45. TaylorWessing. Bridging the funding gap: The financing challenge for European cleantech and renewable energy. (2010). at <http://united-

kingdom.taylorwessing.com/fileadmin/files/docs/BridgingTheFundingGap.pdf>

46. Danielsson, J., Song Shin, H. \& Zigrand, J.-P. Balance sheet capacity and endogenous risk. Working paper 15, (2011).

47. PWC. Financial reporting in the power and utilities industry: International financial reporting standards. (2014).

48. Muradkhanli, N. Natural Gas as a Bridge Fuel into a Sustainable Future for Germany. IAEE Energy Forum (Second Quarter) 41-43 (2016).

49. National Grid. Future Energy Scenarios: UK gas and electricity transmission. (2015).

50. Vos, I. The impact of wind power on European natural gas markets. 01, (2012).

51. DECC. Technical assessment of the operation of coal \& gas fired plants. (2014).

52. POST. The Future of Gas in the UK. 51, (Parliamentary Office of Science \& Technology, 2015).

53. ITRE Committee \& Parliament, E. The impact of the oil price on EU energy prices. (European Parliament, 2014). doi:10.2861/53107 
54. IEA. Coal. 2015, (2015).

55. Davis, S. J., Caldeira, K. \& Matthews, H. D. Future CO2 emissions and climate change from existing energy infrastructure. Science 329, 1330-1333 (2010).

56. Pfeiffer, A., Millar, R., Hepburn, C. \& Beinhocker, E. The ' $2{ }^{\circ} \mathrm{C}$ capital stock' for electricity generation: Committed cumulative carbon emissions from the electricity generation sector and the transition to a green economy. Appl. Energy (In Press), (2016).

57. Sanchez, D. L. \& Kammen, D. M. A commercialization strategy for carbon-negative energy. Nat. Energy 1, 1-4 (2016).

58. Ernst \& Young Global Limited. Benchmarking European power and utility asset impairments: Testing times ahead. (2015).

59. Deloitte. Newsletter: Power \& utilities in Europe. (2015). at $<$ http://www2.deloitte.com/content/dam/Deloitte/dk/Documents/energy-resources/NewsletterPower-and-utilities-april-2015.pdf>

60. Sijm, J., Neuhoff, K. \& Chen, Y. CO2 cost pass-through and windfall profits in the power sector. Clim. Policy 6, 49-72 (2006).

61. Sijm, J. P. M., Bakker, S. J. A., Chen, Y., Harmsen, H. W. \& Lise, W. CO2 price dynamics: the implications of EU emissions trading for the price of electricity. (2005). at <http://www.ecn.nl/docs/library/report/2005/c05081.pdf>

62. Point Carbon Advisory Services. EU ETS Phase II - The potential and scale of windfall profits in the power sector. (2008). at

<http://www.wwf.org.uk/filelibrary/pdf/ets_windfall_report_0408.pdf>

63. National Grid. Provisional auction results: T-4 capacity market auction 2014. (2014).

64. National Grid. Provisional auction results: T-4 capacity market auction for 2019/20. (2015).

65. Stacey, K. UK's green subsidies to end in a decade, says official. The Financial Times (2015). at $\langle$ http://on.ft.com/1ZDmfdK>

66. SSE. SSE statement of capacity market auction provisional results - Fidder's Ferry power station. (2015). at <http://sse.com/newsandviews/allarticles/2015/12/sse-statement-oncapacity-market-auction-provisional-results-fiddlers-ferry-power-station/>

67. Elliott, D. A balancing act for renewables. Nat. Energy 1, 1-3 (2016).

68. Armstrong, R. C. et al. The frontiers of energy. Nat. Energy 1, 1-8 (2016).

69. BMWi. An electricity market for Germany's energy transition: Discussion paper of the Federal Ministry of Economic Affairs and Energy (green paper). (BMWi, 2014).

70. Da Graça Carvalho, M. EU energy and climate change strategy. Energy 40, 19-22 (2012).

71. European Commission. Structural reform of the European carbon market. (2015). at <http://ec.europa.eu/clima/policies/ets/reform/index_en.htm> 
72. Newbery, D. M. Policies for decarbonizing a liberalized power sector. (2016). at <http://www.eprg.group.cam.ac.uk/wp-content/uploads/2016/02/1607-PDF.pdf>

73. Diaz-Rainey, I. \& Tulloch, D. J. Carbon Pricing in New Zealand's Emissions Trading Scheme. Available SSRN 2759284 (2016).

74. Chevallier, J. EUAs and CERs: vector autoregression, impulse response function and cointegration analysis. Econ. Bull. 30, 558-576 (2010).

75. Ellerman, A. D. \& Decaux, A. Analysis of post-Kyoto $\mathrm{CO}_{2}$ emissions trading using marginal abatement curves. MIT Jt. Progr. Sci. Policy Glob. Chang. Report 40, (1998).

76. European Commission. Competition policy brief: Improving State aid for energy and the environment. (2014).

77. Megaw, N. UK energy groups warn subsidy cuts threaten old wind farms. The Financial Times (2015). at 〈http://on.ft.com/1P5WiQT>

78. Brown, J. M., Adams, C. \& Noble, J. UK energy policy slammed as solar company collapses. The Financial Times (2015). at <http://www.ft.com/cms/s/0/f3ff7db4-6d9e-11e5-8171ba1968cf791a.html\#axzz3oYWUxJBj>

79. Mason, R. \& Vaughan, A. Energy minister expects UK to miss renewables target, leaked letter shows. The Guardian (2015). at 〈http://gu.com/p/4e3j5/sbl>

80. Stacey, K. \& Adams, C. UK's high-wire act on power supplies laid bare. The Financial Times (2015). at <http://on.ft.com/20tYpBR>

81. European Commission. Guidelines on State aid for environmental protection and energy 20142020. Off. J. Eur. Union C 200, 1-55 (2014).

82. Rebours, Y., Trotignon, M., Lavier, V., Derbanne, T. \& Meslier, F. How much electric interconnection capacities are needed within Western Europe? 20107 th International Conference on the European Energy Market 1-6 (2010). doi:10.1109/EEM.2010.5558667

83. European Commission. Communication from the Commission to the European Parliament and the Council: Achieving the 10\% electricity inteconnection target. COM(2015), 1-16 (2015).

84. European Commission. Connecting Europe: the energy infrastructure for tomorrow. (2012).

85. Booz \& Company. Benefits of an integrated European energy market. (European Commission, 2013).

86. ENTSO-E. 10-year network development plan. (European Network of Transmission System Operators for Electricity, 2014).

87. Eurostat. Database - Eurostat. 2015, (2015).

88. Gridwatch. G.B. National Grid Status. (2016). at <http://www.gridwatch.templar.co.uk/>

89. ELEXON Ltd. n e t a - the New Electricity Trading Arrangements. (2016). at $<$ http://www.bmreports.com/> 
90. Réseau de transport d'électricité. co2mix mix energetique | RTE France. (2016). at $<$ http://www.rte-france.com/en/eco2mix/eco2mix-mix-energetique-en>

91. De Meulemeester, B. Capacity payments: expensive solution for a non-existing problem. EnergyPost.eu (2014). at <http://www.energypost.eu/capacity-payments-expensive-solutionnon-existing-problem>

92. Moody's. Moody's - credit ratings, research, tools and analytics for the global capital markets. 2015, (2015).

93. ACER. Capacity remuneration mechanisms and the internal market for electricity of 30 July 2013 - pursuant to article 11 of regulation of (EC) no 713/2009. (Agency for the Cooperation of European Regulators, 2013). at <http://www.acer.europa.eu/Official_documents/Acts_of_the_Agency/Publication/CRMs and the IEM Report 130730.pdf>

94. EIA. Electric Power Monthly with Data for February 2016. (2016).

95. Alberici, S. et al. Subsidies and costs of EU energy: final report. (2014).

\section{Acknowledgements}

The authors would like to thank Prof. David Newbery (Judge Business School, Cambridge) for his expertise on the EU energy system. The authors would also like to thank Dr Alex Money (Smith School, Oxford), Ian Temperton and György Dallos (Greenpeace) for their useful comments and insight.

\section{Competing interests}

The authors declare no competing financial interests. 

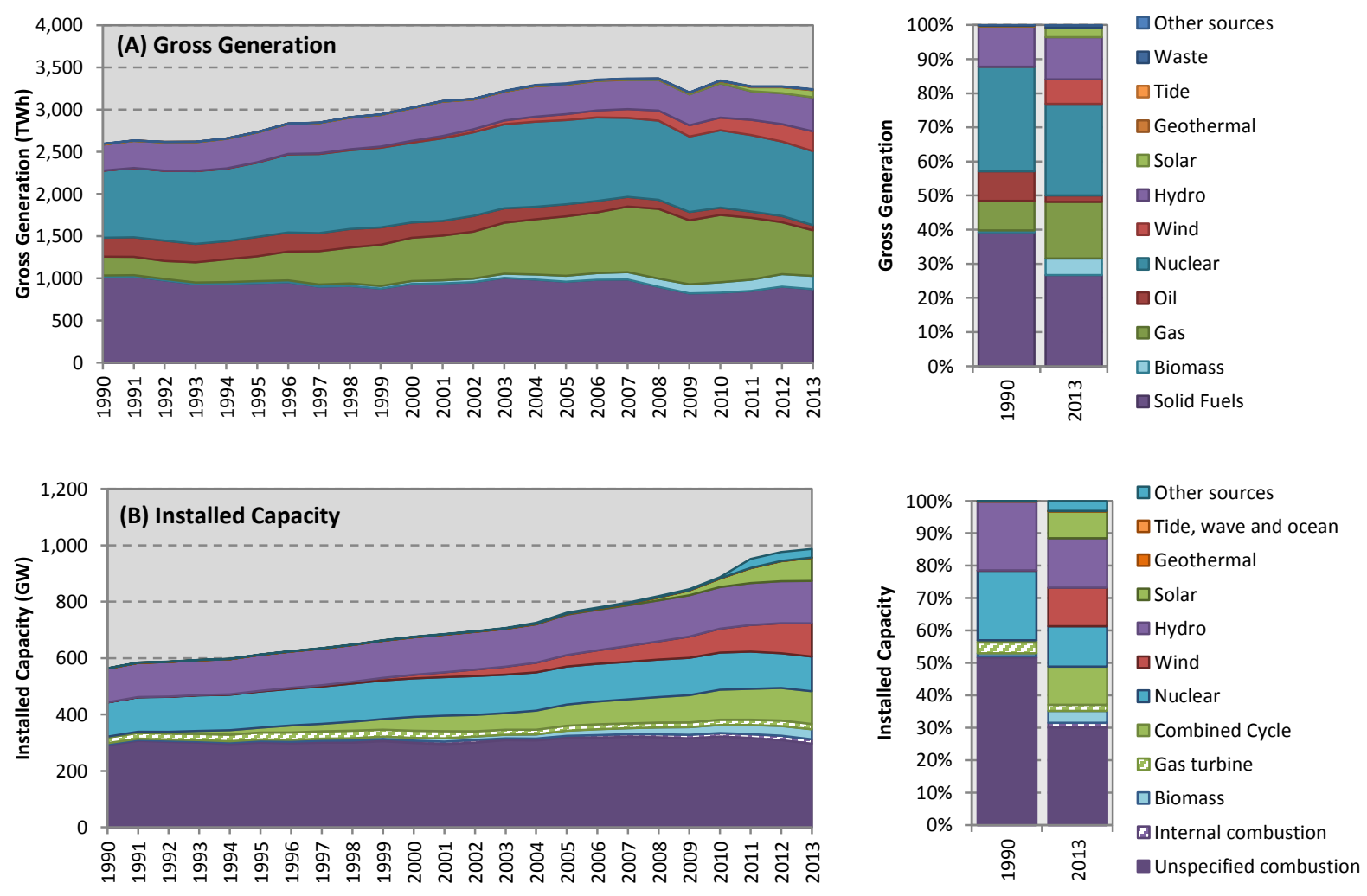

Figure 1: Gross generation and installed capacity in the EU-28, 1996 to $2013 .{ }^{87}$ Plot A presents the gross generation profile of the EU between 1990 and 2013, delineated by generating technology. The plot also illustrates the difference in generation profile between 1990 and 2013, as a percentage of total generation. Plot B presents installed generation capacity between 1990 and 2013, delineated by generating technology. The Plot also illustrates capacity profile in 1990 and 2013, as a percentage of total installed capacity. Note 'installed capacity' is the standard nameplate capacity - the maximum output under optimal conditions. Both figures were compiled using available Eurostat data ${ }^{87}$ from file nrg_105a, using data for EU-28, between 1996 and 2013.

(A) United Kingdom

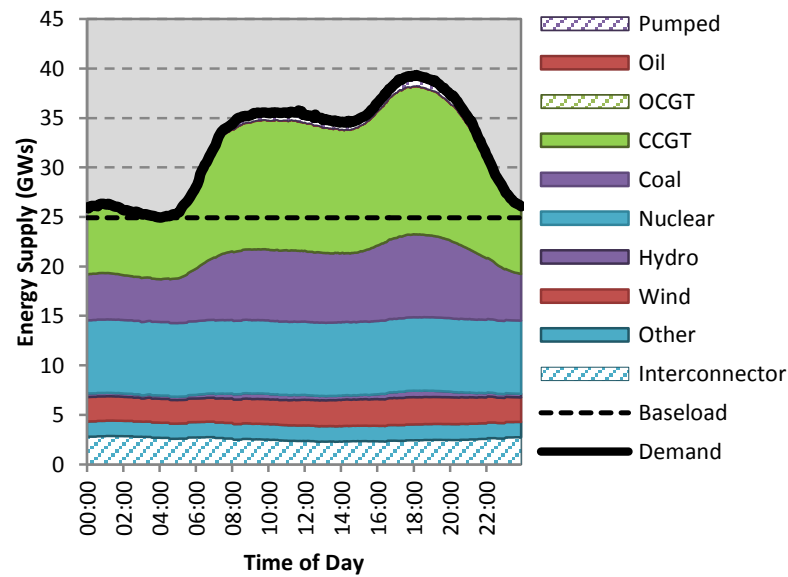

(B) France

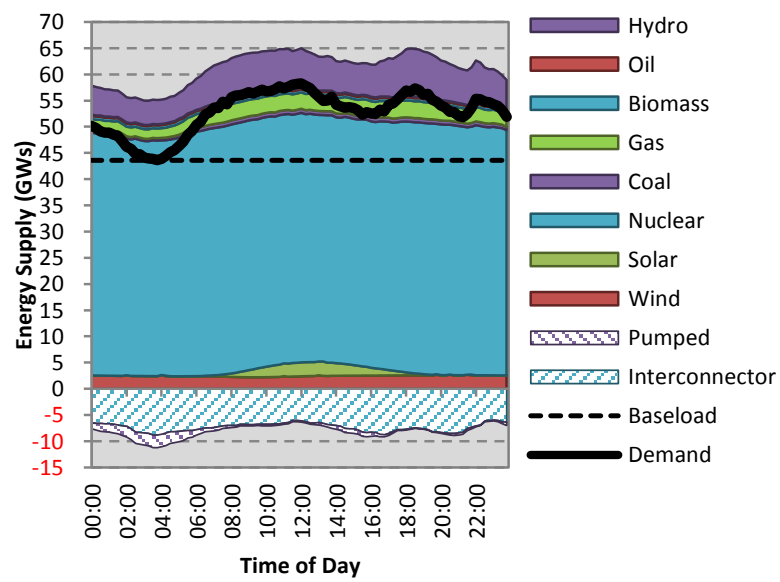

Figure 2: Daily Energy Supply and Demand in the UK and France. Plot A illustrates the daily load profile of the UK, sourced from GridWatch ${ }^{88}$ and courtesy of BM Reports (ELEXON Ltd.). ${ }^{89}$ The figure illustrates that coal and CCGT fluctuate with changing peak demand, whereas RES and Nuclear are typically dispatched at a regular capacity throughout the day. Plot B illustrates the daily load profile of France, also sourced from GridWatch and courtesy of Réseau de transport d'électricité (RTE) France ${ }^{90}$ Both plots contain data from 13 April 2015 to 13 April 2016. The technologies are broadly based on the merit order curve. The UK does not report solar generation. Baseload is calculated as the minimum average daily energy demand. 'Interconnector' is the sum of all imported and exported electricity, where the UK is a net importer and France is a net exporter. 
(A) Merit Order Curve

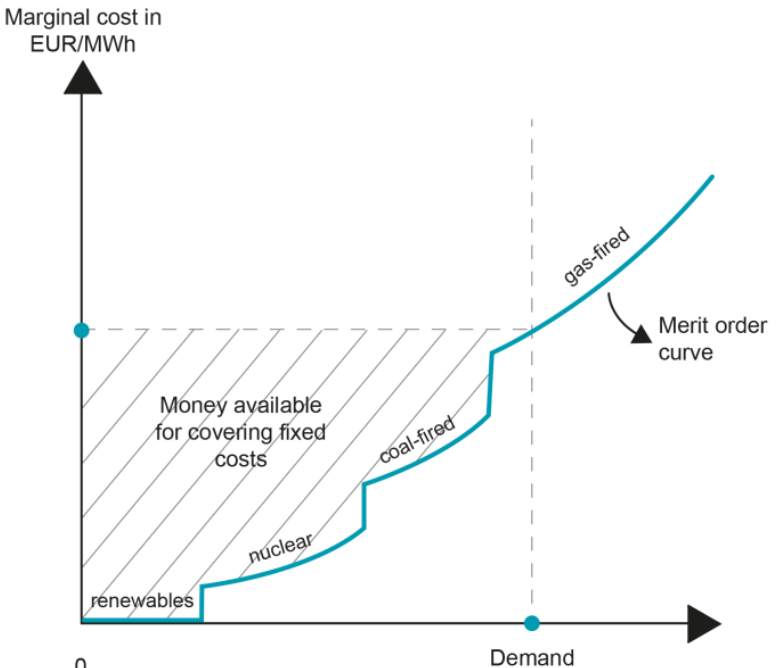

(B) UK Demand, Supply and Price

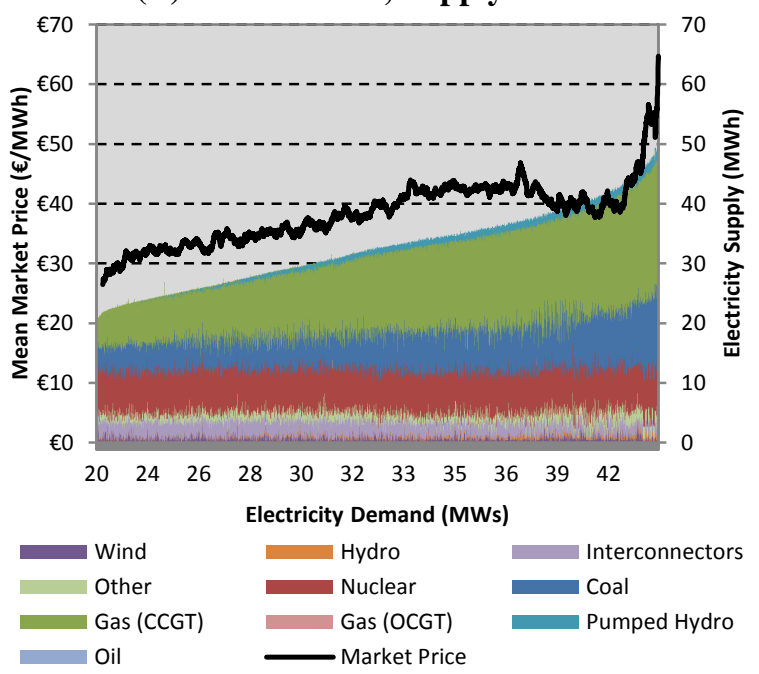

Figure 3: Marginal cost pricing for power supply and Supply-Demand Curve. Plot A illustrates the merit order curve, ${ }^{91}$ which ranks generating technologies on their short-run marginal costs. As demand increases, more expensive technology enters the market and the marginal generator (last dispatched) sets the clearing price. The peaking generators are remunerated during periods of scarcity (excess demand). Plot B illustrates historical supply, demand and market prices in the UK from the N2EX day-ahead, Nord Pool Spot. ${ }^{39}$ Similar to the merit order curve, RES and nuclear are dispatched regardless of demand due to their low SRMC. Peaking units, and expensive CCGT and coal are brought onto the market during periods of excess demand. Accordingly, these marginal generators set the clearing price of electricity.
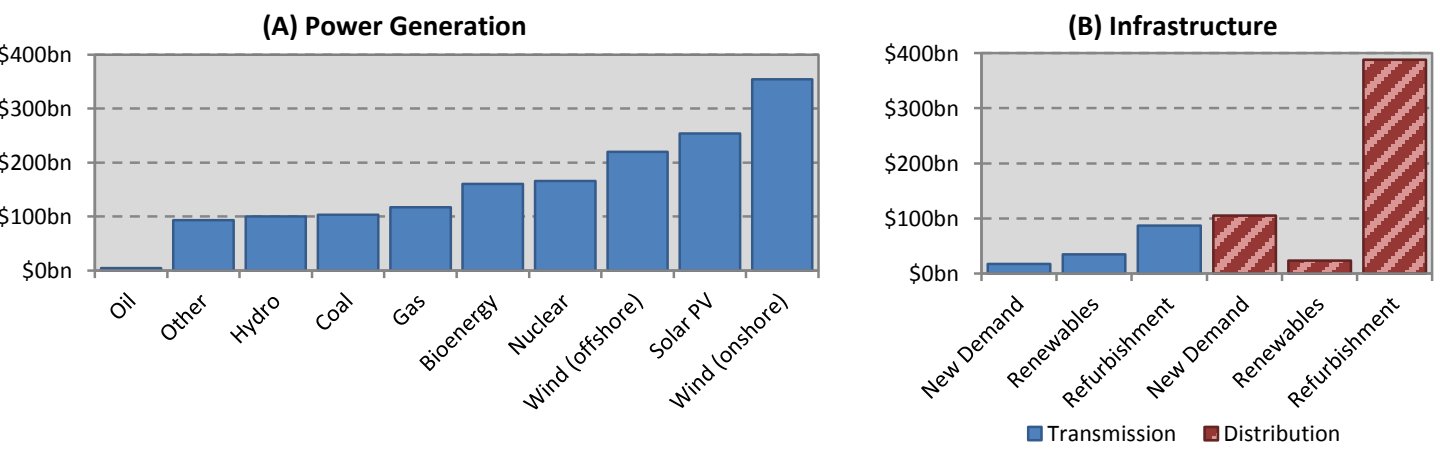

Figure 4: Power generation and infrastructure investments, 2014-2035. ${ }^{8}$ This figure presents IEA (2014) estimates of the required investment capital needed to transition towards a low-carbon energy grid, delineated into generation and infrastructure investments. Plot A shows that the majority of required investment is in lowcarbon technologies. Plot B shows that much of the infrastructure investment is required to refurbish the distribution grid. 

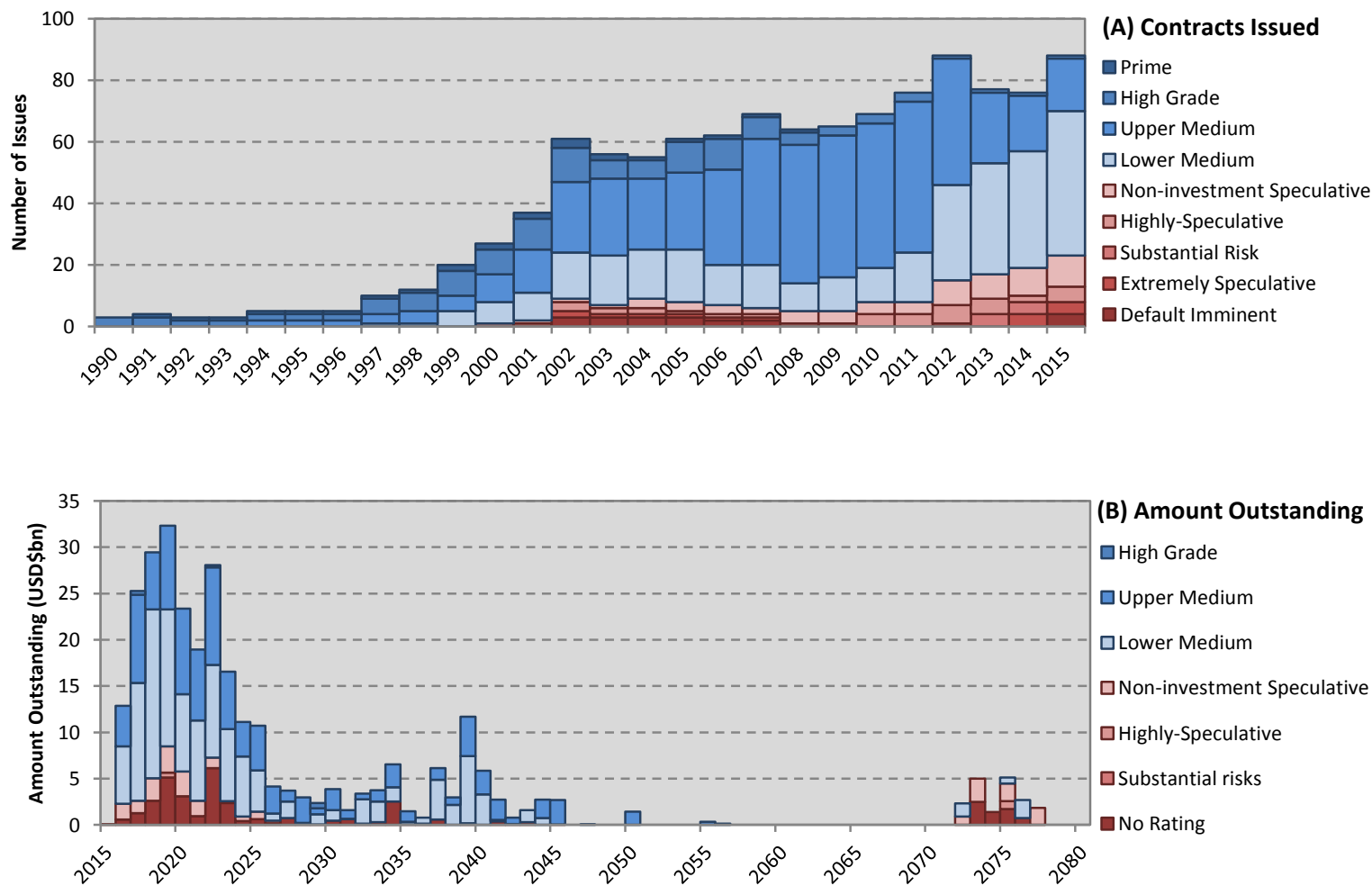

Figure 5: Credit rating of EU energy utilities' debt. This figure provides a combination of Moody's ${ }^{92}$ historical debt issuance records and S\&P Cap IQ data. Plot (A) uses Moody's data on 111 firms to identifying a historical record of debt ratings between 1990 and 2015, presenting the maximum count of observations per rating. Total amount of debt outstanding was not available. Some inter-rating switching occurs across time, but the data is qualitatively similar. The S\&P Cap IQ data aggregates the sum of outstanding debt, per year, for 109 companies with available debt between 2016 and 2080. The debt is delineated into S\&P credit ratings. In both plots, blue represents investment grade bonds, while the red represents non-investment grade.

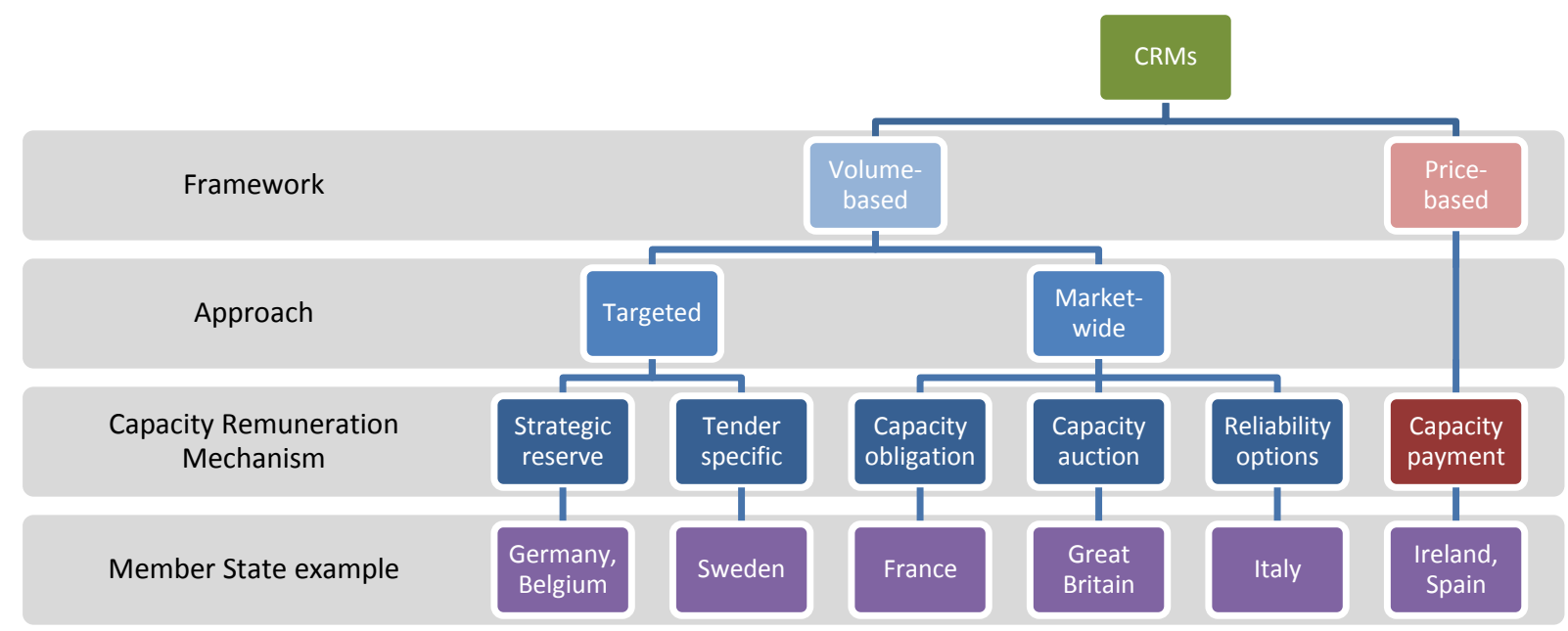

Figure 6: Taxonomy of capacity mechanisms. ${ }^{10,93}$ This figure illustrates a general taxonomy of capacity remuneration mechanisms in the EU. The CRMs can be delineated by volume- and price-based mechanisms. Beyond this, the mechanisms can target capacity or be market-wide. Note, some price-based mechanisms can be targeted. 


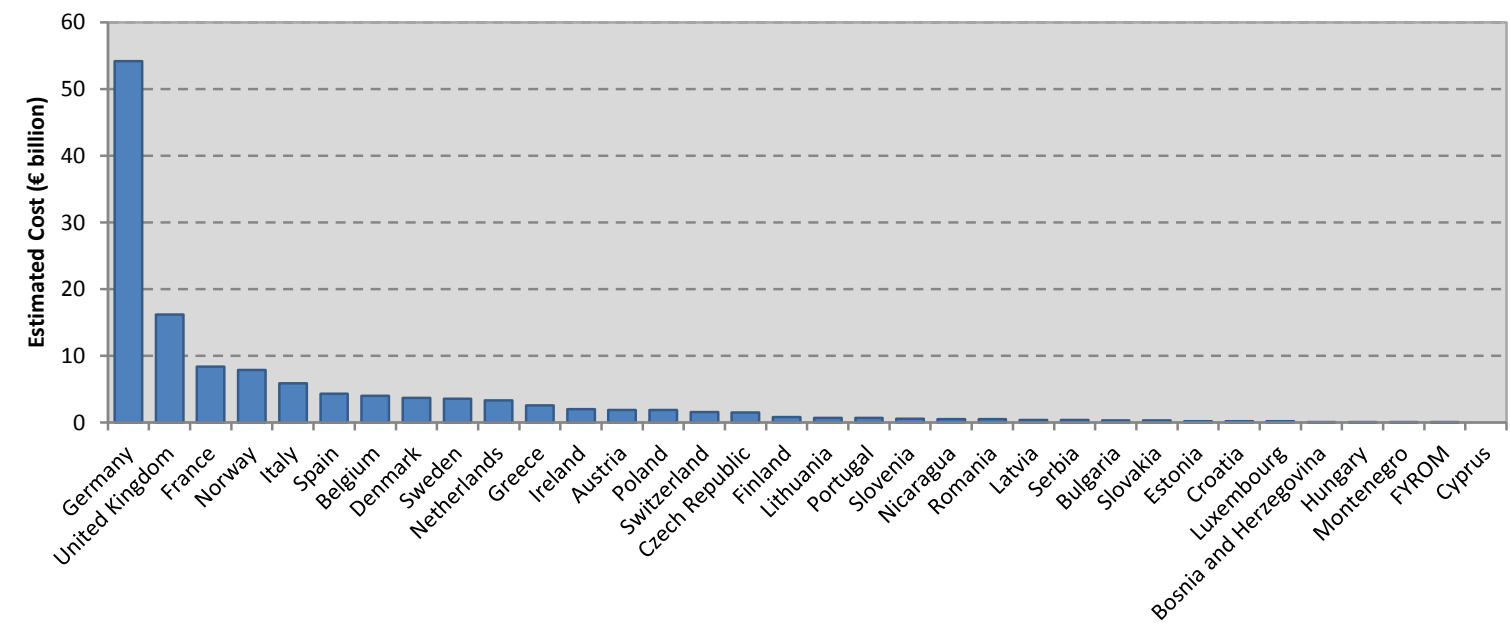

Figure 7: Scale of investment challenge. ${ }^{86}$ This figure illustrates the scale of the investment challenge across EU Member States by 2030.

Table 1: Capacity factors, levelized cost of electricity and subsidies

This table presents the data on average capacity factors, the Levelized cost of electricity, and recent subsidy spending across various technologies. The recent capacity factor data is for U.S. technologies.

\begin{tabular}{|c|c|c|c|}
\hline & $\begin{array}{r}(\mathbf{A}) \\
\text { US Capacity Factor } \\
(2016)^{94}\end{array}$ & $\begin{array}{r}\text { (B) } \\
\text { Levelized Cost } \\
\text { €/MWh (2012) }\end{array}$ & $\begin{array}{r}(\mathrm{C}) \\
\text { Subsidies* } \\
\text { Em (2012) }\end{array}$ \\
\hline Coal & $48.1 \%$ & $€ 74$ & $€ 9,740$ \\
\hline Gas & $\begin{array}{r}\text { (CCGT) } 53.8 \% \\
\text { (OCGT) } 4.4 \%\end{array}$ & $€ 95$ & $€ 6,550$ \\
\hline Petroleum & $\begin{array}{r}\text { (liquid-fired) } 0.5 \% \\
\text { (Internal combustion) } 6.4 \%\end{array}$ & NA & $€ 0^{* *}$ \\
\hline Nuclear & $95.5 \%$ & $€ 100$ & $€ 6,560$ \\
\hline Hydropower & $43.1 \%$ & $\begin{array}{r}\text { (dam) } € 29 \\
\text { (run of river) } € 41\end{array}$ & $€ 5,020$ \\
\hline Wind & $39.9 \%$ & $\begin{array}{l}\text { (onshore) } € 29 \\
\text { (offshore) } € 41\end{array}$ & $\begin{array}{l}\text { (onshore) } € 9,830 \\
\text { (offshore) } € 1,360\end{array}$ \\
\hline Solar PV & $26.6 \%$ & $\begin{array}{l}\text { (small scale) } € 113 \\
\text { (utility scale) } € 101\end{array}$ & $€ 14,700$ \\
\hline Waste & $66.0 \%$ & NA & NA \\
\hline Biomass & $54.8 \%$ & $€ 122$ & $€ 8,310$ \\
\hline Geothermal & $72.8 \%$ & $€ 67$ & $€ 70$ \\
\hline
\end{tabular}

* Subsidies include free allocation of carbon credits.

** Value present but below the level of rounding. 